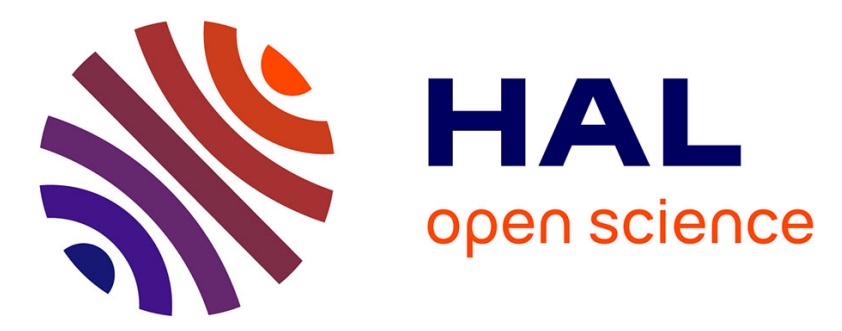

\title{
INTERNAL FRICTION ASSOCIATED WITH GRAIN BOUNDARY SEGREGATION IN Al-Mg AND Al-Na ALLOYS AFTER QUENCHING AND ANNEALING
}

\author{
S. Wu, L. Zhang
}

\section{> To cite this version:}

S. Wu, L. Zhang. INTERNAL FRICTION ASSOCIATED WITH GRAIN BOUNDARY SEGREGATION IN Al-Mg AND Al-Na ALLOYS AFTER QUENCHING AND ANNEALING. Journal de Physique Colloques, 1990, 51 (C1), pp.C1-367-C1-372. 10.1051/jphyscol:1990158 . jpa-00230319

HAL Id: jpa-00230319 https://hal.science/jpa-00230319

Submitted on 1 Jan 1990

HAL is a multi-disciplinary open access archive for the deposit and dissemination of scientific research documents, whether they are published or not. The documents may come from teaching and research institutions in France or abroad, or from public or private research centers.
L'archive ouverte pluridisciplinaire HAL, est destinée au dépôt et à la diffusion de documents scientifiques de niveau recherche, publiés ou non, émanant des établissements d'enseignement et de recherche français ou étrangers, des laboratoires publics ou privés. 
COLLOQUE DE PHYSIOUE

Colloque $C 1$, supplément au $n^{\circ} 1$, Tome 51 , janvier 1990

INTERNAL FRICTION ASSOCIATED WITH GRAIN BOUNDARY SEGREGATION IN AI-Mg AND AI-Na ALLOYS AFTER QUENCHING AND ANNEALING

\author{
S.P. WU and I.D. ZHANG \\ Laboratory of Internal Friction and Defects in Solids; Institute of \\ Solid state Physics, Academia Sinica, Hefei, China
}

\begin{abstract}
The inf tuence of solute segregation on the paraneters of the arain boundary internal friclion puk (CBP) and the hich temperature internal friction peak (tIP) is systenatically studied in two kinds of aluminim alloys (Al--lls and Al--lia). The resulte show that the behavior of intermal friction measured in the two kinds of Al alloys is conpletely different. wich is attributed to different types of arain boundary (FB) segresation. The formation and resolution of second phase particles in GBs which are controled by $\mathrm{Hg}$ atoms non-equilibriun segregation at and back diffusion from GBs after quenchins is the main fackot to change the GBP's paraweters in Al-Hb alloys. A HP wich is found in $\mathrm{Al}-\mathrm{Ha}$ alloy after annealing at appropriate temperature ranse, is surpood to be associated with Na atoms ' equilibriun selective segrestion at GBs which is sensitive to GB structure and teiaperature.
\end{abstract}

\title{
$1 \rightarrow$ INTRODICTION
}

The segresation of solute atoms to $G B$ is bel ieved to occur by two win mechanisms, termed equilibriun and non-equilibriun segergation according to their different drivine force. It is also depended upon the structure of $6 \mathrm{Es} / 1,2,3 \%$. Quenchins and annealins are two basic wethods for producins these two types of CB segergation. Solute segregation is undoubted the nost influential paremeter of che. even the $\mathrm{CB}$ structure itself can be altered extensively by thesegregation $2,4,5 /$. Large changes of interal friction curves associated vith GBrelaxationare expocted as result of solute segresation. Provious results $/ 6,7,8 /$ are winly embodied in the following two aspects. a)change the paraneters of GBP, b)eause new peak other than the CBP. In this paper, it is the propose to study the relation between internal friction and solute GB sogregation in $A$ alloys after quenching and annealing.

\section{2 -- EXPER MEATAL}

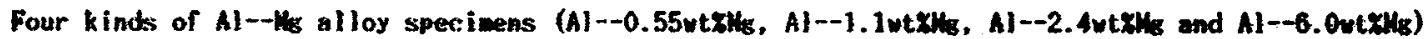
wich are cold drawn from $\$ 3$ to $\$ \ln (R A=89 \%)$ and one Al--Ha alloy specicon(its Ha concentration is within 100ppin to 300pps) which is cold drawn from 4 to 1 in (RA=94x) beve been mensured in the experinent. Before quenching, they vere all annealed at $550^{\circ} \mathrm{C}$ for $0.5 \mathrm{hr}$. to guerentee their aase heat trestent history, their quenching temperature is respectively $350^{\circ} \mathrm{C}, 450^{\circ} \mathrm{C} 、 550^{\circ} \mathrm{C}$ and so on. An inverted torsion pendulue apparatus is used. The situ annealins teaperature cen reach $640 \mathrm{C}$. The oseillation frequency is about thz and the effective lenth of specimens is about 10es.

3 -- RESULTS 
3.1. The influence of $\mathrm{kg}$ concentration on the GBP's parancters after water quenching.

Whe $\mathrm{Kg}$ concentration is 51.1 t 7 , all GBP's parameters realined unchanged vith different quenching condition and subsequently annealins condition $(\mathrm{Kig} .1,2)$. However, when the Ho concentration is $>2.4$ wh. the CBP was greatly suppressed by quenchins, and it vould gradually rise in the annealins procass later on (fic.3.4).

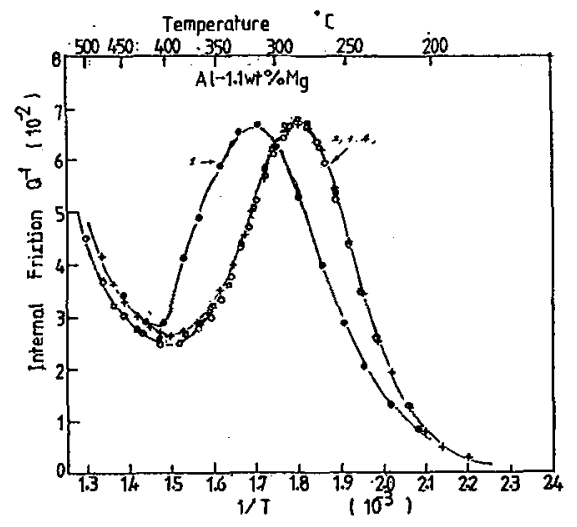

Fig. 1 No effect of quenohing and anneal ing condition on the GBP's Parameters of A1-1. 1wtKMs specimen is observed. Curves 1, 2, 3 corresponding to the GBP during ascending measumement after water quenched from $590^{\circ} \mathrm{C}$ - subsequent descending temperature measumement with annealing time $13 \mathrm{~min}$. at $480^{\circ} \mathrm{C}-3.5 \mathrm{hr}$. at $460^{\circ} \mathrm{C}$ respectively. Curve 4 is the GBP of furnace cooling specimen during descending temperatume measurement.

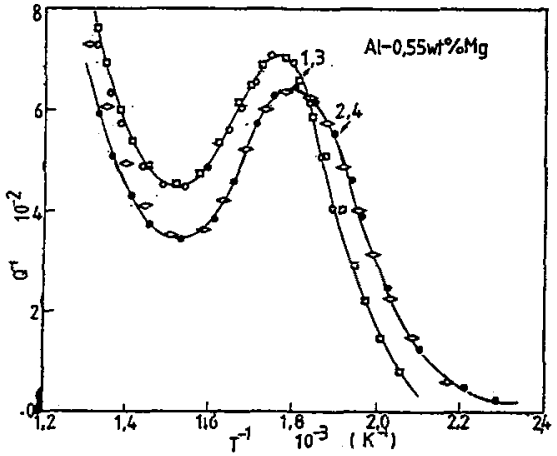

Fis.2 No effect of Tuenohing a annealing condition on the GBP"s parameters of AX--0.55wtrimg specimen is observed. Curves 1,2 corresponding to the GBP during ascending measurement after water quenched fxom $550^{\circ} \mathrm{C}$ - subseruent descending measumement with annealing time 0.Shx. at $485^{\circ} \mathrm{C}$. Curues 3.4 compesponding to the GBP duxing ascending measurement aftex ain cooled from 540'C - subsequent descending metsurement with annealing time $7 / 4 h x$. at $480^{\circ} \mathrm{C}$.

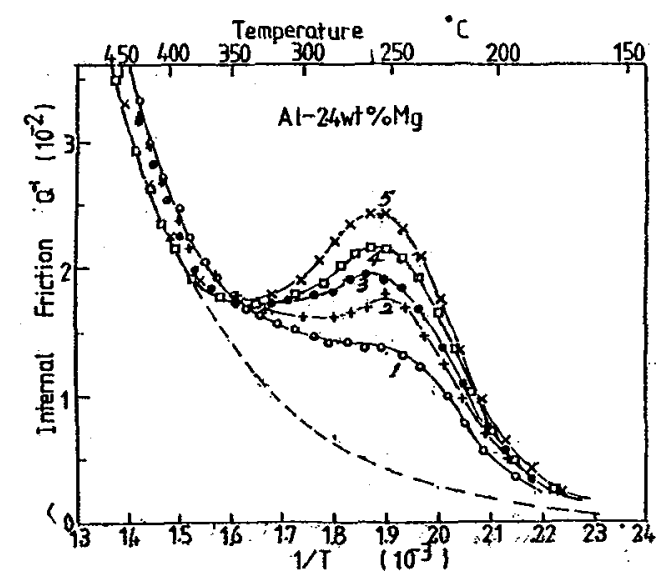

Fig.3 Effect of annealing time at $470^{\circ}$ on GBP of A1--2. 4wt\%Mg after water ruenched from 550 $\mathrm{C}$. Curves $1,2,3,4$, 5 axe for annealing time $15 \mathrm{~min}$. 110min.. 200min. 420min., 910min. respective1s.

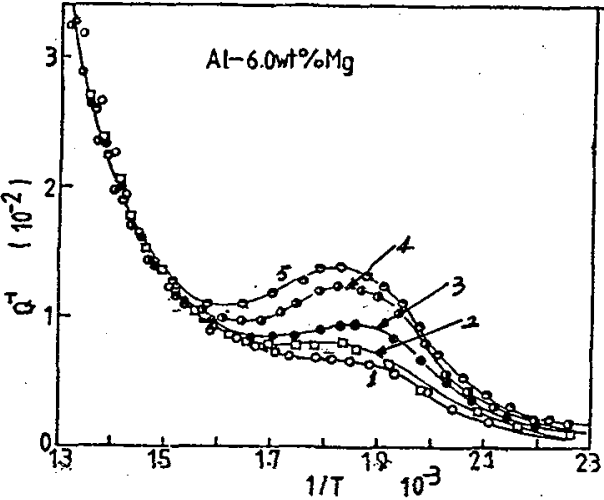

Fig.4 Effect of annealing temperatume and $t i$ an the GBP of Al-6.0wtyos specimen after water guenohed from 550 \%. Curves 1 . 2,3 are for annealing time lsmin., l60min., $420 m i n$. at 470 C mespectively; curves 4.5 are for substruent annealing time $90 \mathrm{~min}$. $310 \mathrm{~min}$. at $520^{\circ} \mathrm{C}$ pespectively.

3.2. The effect of quenching teaperature and quenching way on the GBP's paraneters in Al -2.4wtikg. The higher the quenching temperature and the quicker the quenching speed vere, the more greatly the GBP would be suppressed. Furnance cooling or water quenching temperature $<350^{\circ} \mathrm{C}$ would not suppress the GBP eny core (Fis.5). 
3.3. The effect of annealing temperature and time on the GBP's parameters after water quenching from $550^{\circ} \mathrm{C}$ in $\mathrm{Al}--2.4 \mathrm{wt} \mathrm{xkg}$.

When annealing temperature $\approx 400^{\circ} \mathrm{C}$, the GBP's height which had been suppressed by quenching rose very slowly with annealing time, and if the annealing temperature got as high as $540^{\circ} \mathrm{C}$, the $r$ ise in GBP's height was not obvious either. However, when the annealing temperature is about $470^{\circ} \mathrm{C}$, we could see a clear increment in the GBP's height with annealing time(Fig.6).

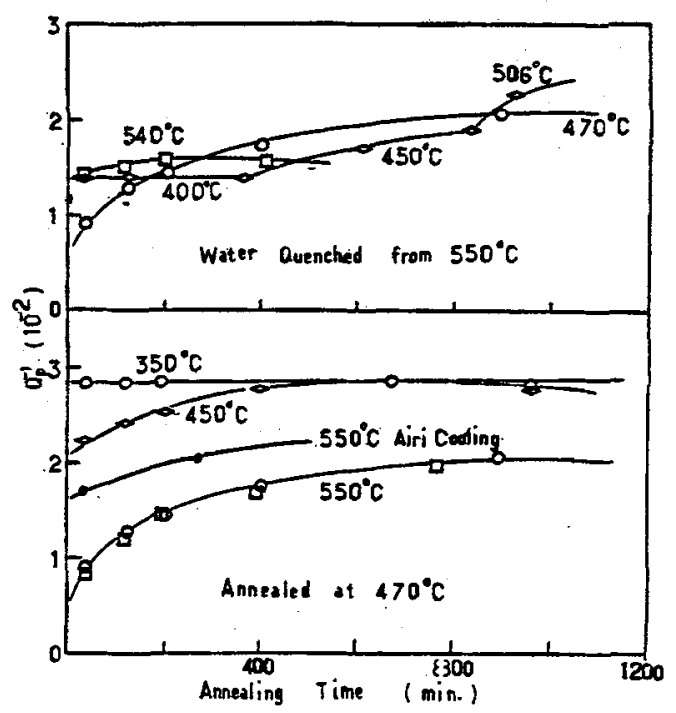

Fig.5 Effect of annealing tempexature on the gBp's height with annealing time aftex water cuenched from $550^{\circ} \mathrm{C}$. The annealing temperatures 1 isted in the figure are $400^{\circ} \mathrm{C}, 450^{\circ} \mathrm{C}, 470^{\circ} \mathrm{C}, 506^{\circ} \mathrm{C}$ and $540^{\circ} \mathrm{C}$ respectively.

Fig.6 Effect of quenching tempewatume and quenching speed on the GBP's height with anrealing time at $470^{\circ} \mathrm{C}$.

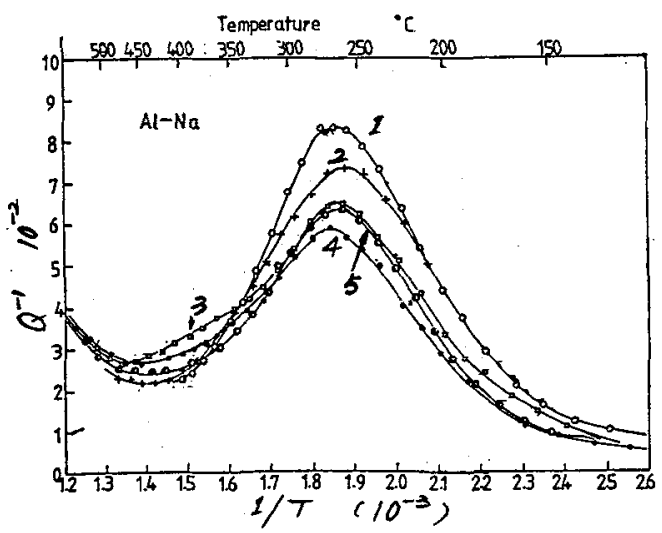

Fis.? Effect of annealing condition on the intexnal friction curses of $A 1-N{ }^{2}$ alloy. 1: $400^{\circ} \mathrm{C}>1 \mathrm{hr}$. : 2 : $478^{\circ} \mathrm{C} \times 1 \mathrm{hm}$.

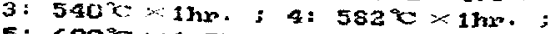
5: $600^{\circ} \mathrm{C} \times 1.5 \mathrm{hr}$.

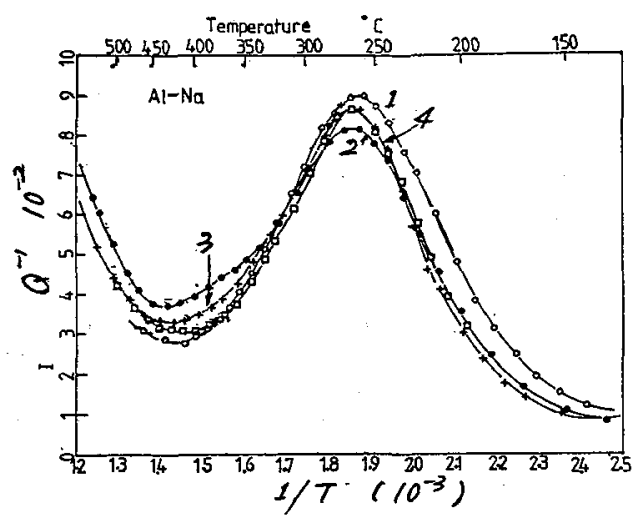

Fig.0. Effect of annealing condition on the intemal friction curves of Al--Na al Iol after water quenching from 5300. 1: $462^{\circ} \mathrm{C}=1.5 \mathrm{hr}$; 2 : $532^{\circ} \mathrm{C} / 3 \mathrm{hr}$ : 3: $550^{\circ} \mathrm{C} \times 1.5 \mathrm{~h}$. then drop the temperature to $474^{\circ} \mathrm{C}$ and for $7 / 3 \mathrm{hm}, 4^{\prime}, 620^{\circ} \mathrm{C} \times 1 \mathrm{hx}$. 


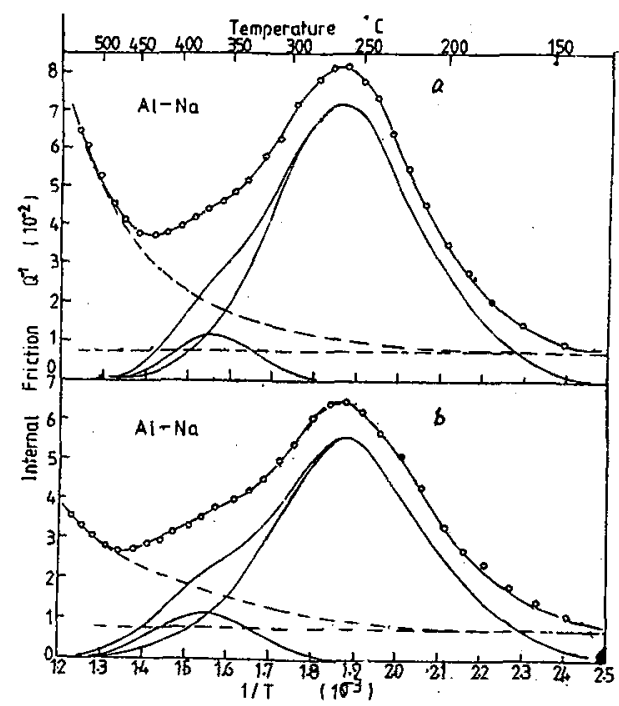

Fig-9 A smal1 peak (co370'C) appears after substraction of the backspound for al-Na specimen. a: anneled at $530^{\circ} \mathrm{C}$ for $7 / 3 h n$ after watew quenching. b: annealed at 540 . for lhw. without quenching treatment.

3.4 The effect of quenching and annealing condition on GBP and HTP in Al-Halloy (Fiz.7,8) The GBP's paraweters were not influenced by vater quenching. Hovever, if the anneal ina temperature reached the range of $510^{\circ} \mathrm{C}$ en $540^{\circ} \mathrm{C}$, whatever quenchins or nut, a sall HTP wold appear (Fic.9) wich was not observed in Al- Hg alloys, higher or lower temperature annealine would not favour its existence. There is a weak growth--decline relation between HTP and GBP.

\section{4 -- DISCISSIOHS}

4.1. Solute atoms ' concentration in GBs and the parameters of GBP

As ve discussed in (S. P. Wu and $L$. D. Zhang, to be published). the solute atons in GBs can give $r$ ise to weak blocking effect on the $G B$ 's sliding. The core solute atoms in GBs are, the simaller the GBP's height vill be.

4.2. Quenching temperature and non-equilibrium $\mathrm{GB}$ segreation

It is know that one of the cost ieportant characters of quenching process is that it can produce a lot of supersaturated quench--in vacancios, and then, there wst exist a vacancy cradient--vacancy flow. The segregation generated by this vacancy flow to Gis can be considered in teres of two processes: i) reverse alow flow which is a direct of vacancy, flow, and II) the dragging of solute atoms by vacancies, i.e. the racancy--solute aton conplex flov. In the first process, the solute atoms and vacaneies wave in the opposite wile in the second they floy in the same direction. hs ins ato is a very effective vacancy trapper, the second process is dowinat after quenching in Al-- Ha alloy, wich can sive rise to the enrichment of $\mathrm{H}_{\mathrm{B}}$ atoms at GRs.

Hov let us discuss the wole Hz atoms non-equilibriun GB segregation process by estiwating sone parameters after quenchins.

a) The concentration of quench--in vacancies way be expressed as: $\Delta C_{v}=K_{V} \cdot \exp (-E \mathrm{f} / \mathrm{KT})$

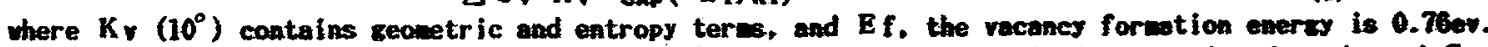

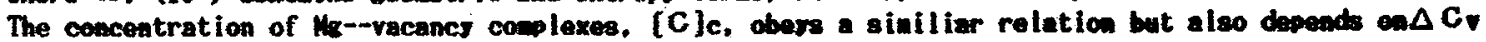
and the bulk concentration, $[\mathrm{C}] \mathrm{s}$ :

$[\mathrm{C}]_{\mathrm{c}}=[\mathrm{C}]_{\mathrm{s}} \cdot \Delta \mathrm{Cv} \cdot \mathrm{Kc} \cdot \exp (\mathrm{E} \mathrm{b} / \mathrm{KT})$

were $\mathrm{Ke}\left(10^{\circ}\right)$ contains geonetric and entropy teres and $\mathrm{E} b$, the $\mathrm{h}$-vacancy bindins eneras. is $0.10 .0 .20 \%$. 
b) The volume ratio $B$ occupied by CBs locates in the range of $10^{-5} \sim 10^{-6}$ if the dianeter of arain and the thickness of $G B$ are $0.3 \mathrm{~m}$ and $10 \%$ respectively.

If we suppose that all the complexes my reach $\mathrm{GBs}$, the increaent of $\mathrm{Hg}$ atons ${ }^{*}$ concentration at GBs reaulted from this he--vacancy flow way be expressed as: $\triangle[C]$ He $\approx[C] \mathrm{c} / \mathrm{B}$

The quentities of $\Delta C v,[C] c$ and $\Delta[C] M g$ are listed in table 1 with different quenching tenperature.

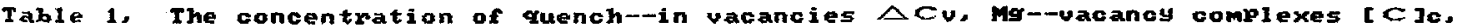
and the incmement of Mg atoms conoentration $\triangle[C J M g$ with different cuenching temperature $T \%$.

\begin{tabular}{|c|c|c|c|}
\hline $\begin{array}{l}\text { Te } \\
350^{\circ} \\
450^{\circ} \mathrm{C} \\
550^{\circ} \mathrm{C}\end{array}$ & $\begin{array}{l}5 \times 10^{-8} \cos 0^{-7} \\
7 \times 10^{-7} \cos 0^{-6} \\
5 \times 10^{-6} \cos 0^{-5}\end{array}$ & $\begin{array}{l}{[c] c} \\
10^{-7} \leftrightarrow 10^{-6} \\
10^{-6}<10^{-7} \\
10^{-9}=10^{-8}\end{array}$ & $\begin{array}{c}\triangle[C] M S \\
10^{-2} \% \\
10^{\circ} \% \\
10^{2} \%\end{array}$ \\
\hline
\end{tabular}

Clearly, when quenching tenperature is as low as $350 \mathrm{C}$, there is 1 ittle increant of $\mathrm{KB}$ atows in GBs,

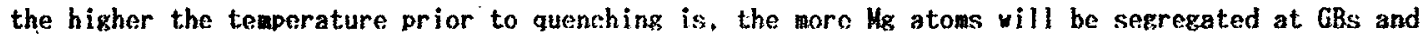
then the nore greatly the GBP vill be suppressed.

As for Al--Ha speciwen, because of its very low bulk concentration and less effectiveness in trapping vacancies, the first process vill be doainant in eliminating those quench--in vacancies. This is not favourable for the enrichnent of Ha atows in GBs, and then not. favourable for any suppression of the GBP and the appearence of the HTP.

4.3. Annealing temperature and $\mathrm{Hg}$ atoms' back diffusion from GBs after quenching--the appearence af Al--He phase in GBs.

The $\mathrm{H}$ atoms wich has been segregated at GBs during a quench are not in theral--equilibriun state. They will be elininated by diffusion frow GBs under certain condition. According to the relation of $T=P \approx v_{0} \cdot \exp (-Q / K T)$

were $P$ is the hoping frequency of $\mathrm{Mg}$ atom fros $6 B, v 0=10 \mathrm{sec}, Q$ is the activation energy of the diffusion process. The datum of $P$ and $T$ are listed in table 2 for different annealing teaperature.

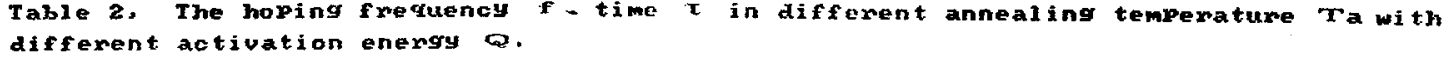

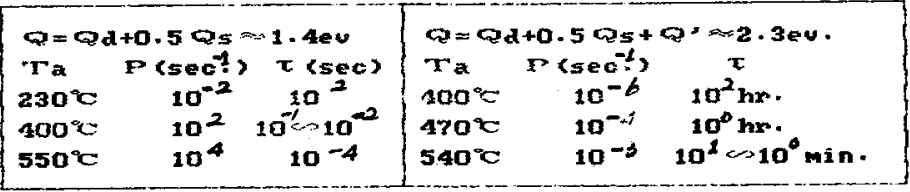

How, if $\mathrm{Mg}$ atoms in GBs are in solid solution state, then

$$
a=0 \mathrm{~d}+0.50 \mathrm{~s} \neq 1.4 \mathrm{ev} \text {. }
$$

where ad (32Keal/wol) is $\mathrm{Kg}$ atoa's bulk diffusion energy and os (1.4Keal/aol) is Ng atom's GB segregation energy. Fro the datum in table 2, ve come to the conclusion that the process of No aton's back diffusion would have been acconplished during the first ascending teaperature process completely, even during quenching process itself! This seem to be corresponding to the case of

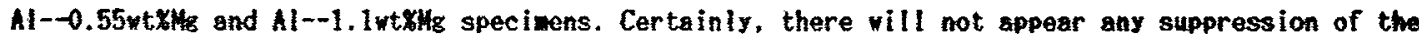
GBP after quenching. However, wen the bulk concentration of Hg gets as high as 2.4wt\%, Hs atcon's enrichment will result in the appearence of $\mathrm{Al}-\mathrm{Hg}$ second phase in GBs. This view point has been supported by phase analysis using $X$-ray diffraction techniques. In this case. resolution of the phase wich acquire activation energy $Q^{\prime}$ ust be in process before $\mathrm{Mg}$ aton's diffusion from GBs. According to the phenomena observed in internal friction curves $\left(T a=170^{\circ} \mathrm{C}, \tau=10^{\circ} \mathrm{kr}.\right), 0,0$. gev. is obtained and the paraeters of $P$ and $z$ for other annealing teaperature are listed in table 2. For $T a \approx 400 \mathrm{C}$, $T$ is too large for 0 so observe the obvious rise of GBP with annealing tine; for Tacn540. C. however. $\tau$ is too small. the process of phase's resolution and $\mathrm{Mg}$ ato's diffusion have been almost accemlished durins the first duscending nessurement. Both the two temperatures are not favorable for us to observe the obvious variation of GBP's paraseters with annenling tive in the subsequent descending mosurement, This is in good agreement with our experiment phenomena observed. 
4.4. The transformtion of GB's structure and the HTP in Al--lla alloy.

The transfernation of $\mathrm{CB}^{\prime} \mathrm{s}$ structure vill occur under certain condition/4,5/. In Al--He allors.the

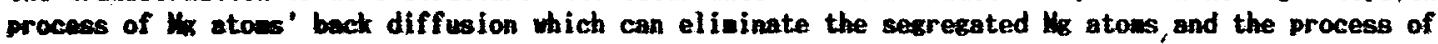
GB's structure transformation which pernits 683 to perserve sore Is atoms are coexistence. High tenperature and high concentration of $H_{8}$ atoms in fils will be favourable to this transformation. This ls the ain reason that the CBP's saturated hoicht can aot return to its initial position after high tenperature $\left(550^{\circ} \mathrm{C}\right)$ quenching or during high teaperature $\left(540^{\circ} \mathrm{C}\right)$ annealing.

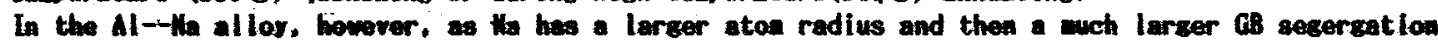
ewerty, Its equilibrius sesregation vill be stronger and core sensitive to GB structure: i.a.

selective segrepation at GBs. Those GBs in wich exist sore lia atoss attribute the HTP. and those vith relative fewer $\mathrm{ta}$ atoms attribute the originsl GBP. Because the annealing temperature is one of the in foctors for the trensfornation of GB's structure wich nay result in increment of He atoms" concentration in GBs, the appearence of the HTP will be ereatly influenced by it.

\section{REFEREYCSS}

1/ D. Melean. "Grain Boundaries in Metals". J. Yiley, 1957

12 H. Uiederalch and P. R. Okasoto. "Interfacial Segregation Paper Preeented at a seninar".1977

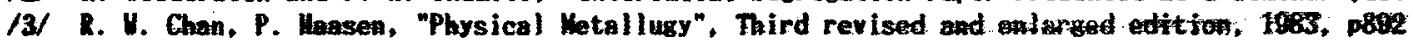

/4 V. Vitek and Gui-Jin Vens, Surfece Sclence, 144, 110-123, 1984

15/ J. A. Eastman. K. E. Sickafus and S. L. Sass, Grain Boundary Structure and Related Phenomena Proceedings of JIXIS--4, 1886

16. Jiane Zi--Ying and Cai lei--Ping, J. de Physique, 46, c10--383, 1885

M7 A. S. Howiek and 8. S. Berry. "Anolastic Relaxation in Crystallina Soltids". Acadowic Preas, 1072, 04:5 